\title{
The Syntactic Functions of Conversational Implicature Utterances with Academic Context: Pragmasyntactic Studies
}

\section{Suhartono}

Universitas Negeri Surabaya, Indonesia

Email Correspondence: suhartono@unesa.ac.id

\section{Background:}

Abstract

Pragmatic analysis has been widely developed through the use of an implicature. This paper tries to focus on the syntactical functions elaborated from an academic discourse as the focus of analysis. This study aimed to find the syntactic function of conversational interference spoken by speakers in academic contextual communication. The syntactical functions were identified in three parts: predicate, subject, and adverbs.

\section{Methodology:}

To achieve this objective, data in the form of oral statements with academic background were collected using note-taking techniques from 114 subjects through participant observation in lecture activities, online and offline meetings, discussions, final project consultations, and training. The data was analyzed using the Miles and Huberman flow technique through data reduction, data presentation, and the conclusion/verification of data analysis results.

\section{Findings:}

Results show that pragmatic expressions that can help the speaker to identify the intent of the speaker were positioned as fillers of predicates, subjects, and information. This pragmatic expression is the impact of the incomprehensibility or inconsistency of the narrator with the speaker who was previously the listener. For the sake of completeness, speakers add other pragmatic expressions with substitution strategies, additions, and conditional forms with an orientation that prioritizes politeness by avoiding direct speech with the negation of 'tidak (no),' 'belum (not yet),' 'bukan (not)' and 'jangan (not).

Keywords: syntax function; conversational implicature; academic context; pragma syntactic.

\section{DOI}

Received

Accepted

Published

Copyright Notice
: $\quad$ http//dx.doi.org/10.24903/sj.v5i2.572

: August 2020

: $\quad$ September 2020

: $\quad$ October 2020

Authors retain copyright and grant the journal right of first publication with the work simultaneously licensed under a Creative Commons Attribution 4.0 International License that allows others to share the work with an acknowledgment of the work's authorship and initial publication in this journal.

\section{INTRODUCTION}

In communication with academic backgrounds, such as lectures and exams, with certain considerations, many speakers convey their meaning through conversational implications (Suhartono, 2020a). Cruse (2000); Koktová (1998); and Mey and Brown (2009) point out that the implication of conversation is a meaning that is not stated (not encoded) in a statement that is explicitly spoken. Leech (1983) and Ariel (2008) suggest that interpreting the intentions of the speakers in a conversational context requires the inclusion of the context of the speech through heuristic analysis, and conveying meaning through conversational implications causes the speech of the speaker to lose its role because it is replaced by context. The role of context 
becomes dominant as if the intention of the speaker can not be understood without the full involvement of the context, pragmatic expressions in the form of words and phrases in speech can be ignored.

Analysis of conversational implicature emphasizes o two arguments. First, in the production process of utterance, the speaker optimizes the role of pragmatic expressions that fill the syntactic function of speech so that the literal meaning of the utterance can be understood by the hearer. Understanding the literal meaning of speech, combined with context analysis, becomes the basis for interpreting the intent of the speaker (Suhartono, 2020c). This suggests that the interpretation of the intent of the speaker is not entirely determined by the context, because there is a role for the literal meaning of the utterances, even though that role is not dominant. Second, the interpretation of the intent of the speaker is conveyed through a conversational implication. Cruse's (2000) argues that interpretation can be made through the construction of the premises concerned. The premise is constructed by the delisting of certain syntactic functions. For example, if A asks, "Can Mrs Marry's article be published in the next issue of our journal?" and B replies, "Too few data," B's statement implied that Mrs Marry's article could not be published. The implication of this conversation is part of the premise that implies that 'Mrs. Marry's article cannot be published in the next edition of our journal because the data is too little.' If the premise is examined, 'data is too little' positioned as a filler of the 'adverb' syntactic function that helps interpret the intent of the speaker.

Based on these arguments, exploring the syntactic function in speech with conversational implications and explaining the strategies used by speakers to add pragmatic expressions to their speech may be new to interpreting the intent of the speaker. Theories in this study are underpinned on two main concepts: conversation implicature and syntactic function.

Conversation implicature in a pragmatic is originated by Grice (1975) emphasizing what is implied or something more than stated. In Grice's (1975) view, implicature consists of conversational implicature and conventional implicature. Implicature entails (i) the act of meaning or implying one thing by saying something else, or (ii) the object of that act. Grice (1975) emphasizes an implicature to explain and predict conversational implicatures and describe how they arise and are understood. Conversational implicature or simply defined as an implicature indicates an indirect or implicit speech act to show a speaker's utterance that is not explicitly said. The opposite of implicature is of explicate to refer to explicit utterances. A review of the literature shows that conversational implicatures are embedded by the context of conversation, and conventional implicature is subject to the convention (Suhartono, 2020b). Implicature, thus, defines the way an interpretation of a speaker's intention is understood in a 
conversation (Suhartono \& Yuniseffenri, 2009). This regards the conversation as the sources to which the meaning of a message is endorsed considering the intended meaning of an utterance implicitly and explicitly.

Conversational concerns is a technical term in pragmatics originally introduced by H.P. Grice in his 1967 lecture. In Grice's (1975) view, the term developed from the verbs involved (implies) means "what is implied" or "something more than stated" that results in the implicature. Implicatures are broadly grouped into: conversational implicatures and conventional implicatures. Suhartono's (2020b) argues that conversational implications are bound by the context of conversation, whereas conventional implications are bound by convention. In contrast to the conversational implications, which are the interpretation of the speaker's intentions based on the speaker's remarks and the context of the conversation, the interpretation of the speaker's intentions in conventional contexts is based on the conventions that the speakers have adopted (Suhartono \& Yuniseffenri, 2009).

The concept of conversational implicatures is the result of developing speech act theory (Suhartono, 2020c). In Austin's (1962) view, a speech act is an activity to convey meaning through utterances "intent" in his view it needs pressure because it relates to the purpose of communication, and consist of three components, namely locus, illocution, and perlocution. The act of locus is the act of the speaker in expressing utterance. The product of locus action is the performance of an sich utterance, in the sense that it is not accompanied by a notion of intent and power. In Yule's (1998) view, the act of locus is the basic act of an utterance because the product in the form of speech performance becomes the basis for the analysis of the speaker's intent.

In contrast to the act of locus, the act of illocution is the act of a speaker in conveying their intentions through utterances. This illocutionary act becomes the center of attention in speech act theory (Leech, 1983). From another perspective, Yule (1998) argues that illocutionary acts are displayed through the communicative power of utterances. This communicative power is often called illocutionary power. The power of illocution, according to Allan (1998), is what speakers do in their utterances.

The third type of action, perlocution act, is the act of a speaker in delivering utterance that has the power to influence, clarify, and so on. The act of perlocution, like acts of locus, in many studies, has been marginalized due to its strategic and substance dominance of illocutionary acts. Leech (1983) argues that strategic inter-speech acts are not the same. In his view, without wanting to rule out localization and perlocution acts, the most important act in Austin's speech act theory is the act of illocution. In agreement, Dik and Kooij (1994) and Berge (1994) define 
illocutionary acts are the main aspect of communication, the reality of developing speech act theory that focuses on illocutionary acts, as was done by (Bach \& Harnish, 1979; Searle, 1975; Searle \& Searle, 1969), and the next generation of pragmatics experts. The implicature of conversation, for example, is the result of the development of illocutionary acts that continue to develop in various contexts in many countries.

In further developments, implicature concerns with politeness that represents the motivation of speakers in conversational implicatures (Leech, 1983). Brown et al. (1987) emphasize that politeness is the use of facial notions or self-images (face). The term "face", which in this context is translated as face or self-image, was originally used by Goffman in 1967. The word was originally a vocabulary for a particular regional language which was then absorbed and made into a separate entry in English. As seen in the use of the terms "losing face" and saving face, "face" is a term meaning image or self-esteem that is emotionally embedded (invested), and things that are embedded can be hurt, ignored, eliminated, guarded, maintained, enhanced, cared for (attended), and so on in interaction (Brown et al., 1987).

In addition, Brown et al. (1987) divide politeness into negative politeness and positive politeness. Negative politeness is politeness with a negative face. The orientation is saving a negative face. On the contrary, positive politeness is politeness with a positive face. This kind of politeness is oriented towards saving positive faces. In contrast to Brown et al. (1987), Leech (1983) argues that basically language politeness is related to the relationship between two participants which he calls "self" and "other". In conversation, "self" is identified as a speaker, while "other" is identified as a hearer. However, speakers can also show politeness to other people who are present or not present in the speech situation. Therefore, the concept of "other" in addition to referring to the speaker is also anyone who can be marked by pronoun III, both singular and inclusive.

Politeness is influenced by several factors. The key factor is the presence or absence of the other person. Another factor is that the other person is under the influence of the speaker or speaker. In this regard, the degree of politeness is positively correlated with the degree of discontinuity and also the speaker's degree of freedom. This means that the more polite the speaker's speech, the less direct the meaning is conveyed and the freer the speaker. The converse has implications that are also the opposite. What is interesting to note in this connection is that being too polite can lead to a pragmatic paradox. This pragmatic paradox is not only in the form of conflicting attitudes between speakers and speakers (Fajaruddin, 2011; Leech, 1983), but also in the form of rigid communication because speakers and hearer are too careful in maintaining the safety of the faces of the speech partners. 
Utterance with conversational implications Suhartono \& Sodiq (2019), is spoken by speakers through several stages. First, the stage of deciding what to say. At this stage, the speaker decides whether he will approve, reject, explain, and so on. Second, the exploration stage of knowledge relevant to decision making in the first stage. Third, the linguistic construction stage which includes segmental construction (discourse construction, sentences, words, and phonas) and suprasegmental (accent construction, intonation, and so on). Fourth, the phonological representation stage.

Sentences may have different communicative functions as they are expressed in different structures. A speaker declaring something is true will use a declarative sentence, to issue an order, request, or command, he/she uses an imperative sentence (Abdul \& Qassim, 2015). The syntactic functions that can be used in the analysis of speech constituents with a conversational implicature consist of predicate, subject, object, complement, and description. The predicate is the most important (main) syntactic function because it is mandatory for all types of sentences (Sugono, 2013). Predicates are descriptive of the subject. In general, predicates are the answer to questions to ask questions other than "what" or "who" (Alwi et al., 2019). In sentences constructed of nominal phrases, the predicate can be recognized by adding the particle "-lah" or identifying the syntactic function with a descending tone (2-31 in the subject-predicate pattern and 2-32 in the predicate-subject pattern) (Alwi et al., 2019). This recent study examines how implicatures are developed in the context of academic context. The focus of this recent study is laid on how sentences are elaborated on their syntactical functions to promote the implicatures. Sentences are elaborated into subject, predicate and their complement to define how implicature strategies are developed. Syntactical function as the main focus of this study differs from the analysis of conventional conversation to which the pragmatic analysis that stresses meaning, decoder and encoder are defined.

The syntactic function close to the predicate is subject. The subject is a syntactic function of the companion of the predicate (Parera, 2009). As a companion to the predicate, the subject can be located to the left or right of the predicate (inversion). The subject is a syntactic function described by the predicate. In a sentence constructing a nominal phrase-nominal phrase, the subject cannot be added with the particle "-lah". Besides, the intonation increased (2-23) in the subject-predicate pattern and relatively flat (2-21) in the predicate-subject pattern. In general, the subject is the answer to the question saying "what" or "who" (Alwi et al., 2019).

Objects are syntactic functions that are close to predicates and objects (Sugono, 2013). The object must come after the transitive verbal verb or phrase. The object is located after the predicate. Like subjects, objects are usually nouns, nominal phrases, or clauses. If the object is 
a noun, lifeless nominal phrase, or single person III; the object noun can be replaced with the pronoun "-nya". If the object is the pronoun "kamu (you)" or "saya (I)", "kamu (you)" and "saya (I)" can be replaced with the "- $m u$ " and "- $k u$ " enclosures. The object can be the subject in the passive voice. The potential for recovery of object constituents with "-nya" and their placing into the subject of passive sentences is a distinguishing feature of complementary words (Alwi et al., 2019).

Syntactic functions that are parallel to the object are complementary (Sugono, 2013). The complements are generally in the form of nouns, FN, or clauses. Complements are not required in sentences. Complement is located behind the intransitive verb or verbal phrase. The complement is located behind the adjective or adjective phrase in a stative sentence (a sentence predicated on an adjective or an adjective phrase). The complement is located after the object (Nordquist, 2019).

Scientifically, this study contributes a theoretical perspective in that syntactic functions are meaningful for the conversation analysis. The roles of subject, predicate, and complement especially the adverbs are prominent in defining pragmatic goals, the intention of a message, and define the implicatures of a discourse. Pragmatic analysis that applies the text analysis approach can be varied their focus delineating the syntax function. To this end, this study aims to see how conversations are examined based on the subject of an utterance, the predicate of an utterance, and the adverbs of an utterance.

\section{METHODOLOGY}

This study records oral utterance in communication with lecture background, final assignment guidance, and examinations at the S-1, S-2, and S-3 levels at the State University of Surabaya; research assignment at the Postgraduate of State University of Surabaya; online and offline meetings on the management of study programs at several universities in Indonesia, PISA training, and the preparation of an independent learning curriculum at several universities in East Java. The number of subjects was 114 people with minimum education of S-1. A total of 24 people work as teachers, 37 lecturers, 9 employees, and 44 students from S-1 to S-3.

The data collected using the note-taking technique in participant observation activities were analyzed using flow techniques. Following (Miles et al., 2014; Miles \& Huberman, 1994), the flow technique data analysis was carried out in three stages, namely data reduction, data presentation, and inference/verification. At the data reduction stage, data preparation is carried out to present data. In other words, at the data reduction stage, data organization and systemization are carried out following the needs of solving research problems. The main 
activities in the first stage are sorting, sorting, classifying, and coding data. After being systematically organized, at the presentation stage, the data were selected by referring to the principle of equality in difference and difference in similarity (similative-distinctive) and considering the adequacy and adequacy of quantity and quality. In other words, the principle of presenting the data used is that the data and its explanation meet the explanative adequacy requirements. In the conclusion and verification stage, which is the final stage, the important points of data analysis and explanation are reduced to conclusive statements as short answers to research questions.

\subsection{Predicate}

\section{FINDINGS}

Predicative syntactical functions in a conversation are characterized by the use of verbs as a predicate to express an intention of a speaker. Pragmatic expressions of predicate fillers or predicate constituents in utterance with conversational implications are seen in Jay's utterance on data (1), Saf on data (2), Lid on data (3), Ris on data (4), Luf on data (5), and Tin on data (6).

(1) Hen: Pak Jay, ternyata semua Renstra dari awal hingga 2030 juga harus ada. Pak Jay bisa bantu?

(Mr. Jay, it turns out that all strategic plans from the start to 2030 must also be in place. Can you help me?)

Jay: Tim sekarang bisa bantu, Bu Hen.

Context:

(The team can now help, Mrs. Hen)

Hen is the head of the study program who coordinates the preparation of accreditation documents. Jay is the head of the study program who was replaced by Hen. In Hen's view, the 2006-2030 strategic plan was Jay's responsibility when he became the head of the study program. Jay is of the view that the strategic plan he did not compile when he was head of the study program is the responsibility of the current meditation team. Jay is not currently a member of the accreditation team.

(2) Har: Bab IV sudah selesai, Mas? (Chapter IV is finished, Sir?)

Saf: Masalah pertama dan kedua sudah selesai, Pak. (The first and second research questions are resolved, Mr.)

Context:

Saf is Har's thesis guidance. He is currently consulting on chapter IV. There are three research questions in his thesis.

(3) Har: Kalau saya usulkan lima reviewer lagi masih ada space?

(If I suggest five more reviewers, is there any space?)

Lid: Perlu dua puluh reviewer kan, Pak?

(It needs twenty reviewers, right, Sir?) 
Context:

Har and Lid are journal managers at a university. The journal is published twice a year and per issue consists of ten articles per article reviewed by two reviewers. The issuance of the last two editions was less orderly and because of that, there will be rearrangements so that next year can index Sinta. One of the things that will be arranged is the addition of reviewers, including the involvement of reviewers from abroad.

(4) Har: Sekarang tinggal bersama ayah?

(Now living with your dad?)

Luf: Tinggal di kos, Pak.

Context:

(Live in a boarding house, Sir.)

Luf consulted about the doctoral studies (S3) that he would undertake at a university in Surabaya. In consultation with Har, head of the S-3 study program, he talked about the difficulty of studying costs and hopes to get a part time job. In addition, his father and mother divorced so that in matters of tuition fees they could not provide a solution. His father has remarried and lives in Surabaya, while his mother lives in Malang, about $100 \mathrm{~km}$ from Surabaya.

Another phenomenon that is present in the maintenance of predicate constituents is that these constituents undergo modification in the form of morphological deletions.

(5) Har: Mbak, kemarin ada ujian Pak Ko dan Pak Tan. Honor penguji eksternal sudah ditransfer?

(Ma'am, yesterday there were Pak Ko and Pak Tan exams. External tester fees have been transferred?)

Tin: Menunggu ST, Bapak, baru transfer.

(Waiting for ST, Sir, then transfer)

Har: Coba nanti saya ke bawah.

(I'll try to go down later)

Context:

Har is the head of the study program which handles closed exams. Pak Ko and Pak Tan are

S-3 students who have just had closed examinations, while Tin is an educational staff who handles honorarium for external examiners in closed exams. Communication between Hard and Tin takes place in Tin's room on the $2^{\text {nd }}$ floor. ST (letter of assignment) processors are education personnel who bear on the $1^{\text {st }}$ floor.

The predicate in Jay's utterance is in "bisa bantu (can help)" because it explains "the current team" which is a pragmatic expression of the subject filler. Jay's utterance implies that Jay can't help it. The constituent "bisa bantu (can help)" is found in both utterance and implicature. This means that identifying Jay's "bisa bantu (can help)" utterance helps the speech partner (Bu Hen) understand Jay's implications. 
If you look at Jay's implicature, it appears that before Jay's utterance was conveyed, Jay intended to convey his disapproval. In this case, there are two options he can do. First, he uses the pragmatic expression "saya (I)" as the filler of the subject, the consequence of which is to use the pragmatic expression "tidak bisa bantu (cannot help)" as the filler of the predicate. When this is done, the speech does not have a conversational implication and it conveys the point directly. In terms of politeness, this is not good because the disagreement is conveyed directly. In other words, he violated the maxims of the agreement and that means his utterance was not polite. In the second option, Jay uses the pragmatic expression "bisa bantu (can help)" as a filler in the predicate. Consequently, he has to substitute the pragmatic expression "saya (I)" with "tim sekarang (present team)" as the filler of the subject. The utterance is polite because the disapproval is conveyed indirectly. Besides, the utterance is polite because it gives praise to the "tim sekarang (present team)" which indirectly implies that The "tim sekarang (present team)" is competent.

\subsection{Subject}

Subjective syntactical functions of an utterance are colored with the identity of the speaker's intention as located in the subject of a sentence. Like predicates, the subject is also a syntactic function filled with pragmatic expressions, aiding the identification of a speaker's intent. As it is a syntactic function described by the predicate, the subject of Mul's utterance on data (6) include An on data (7), Ul on data (8). Pragmatic expressions as predicate fillers or subject constituents that are also present in the speaker's implicature make it easier for speech partners to interpret the speaker's intent.

(6) Hen: Teman-teman tanya surat tugas. Sudah selesai ya, Pak? (My friends asked for an assignment letter. Is it finished, Sir?)

Mul: Surat sudah saya proses lama, tapi kemarin diminta lagi katanya. Context:

(I have processed the letter for a long time, but yesterday he asked again, he said)

Hen is Mul's head in a department at a university. Mul is in charge of submitting a letter of application for an assignment letter to the faculty.

(7) Kho: SKS Bu An sudah cukup?

(Is Bu An's SKS enough?)

An: Kalau tambah disertasi dan publikasi SKS saya 46.

(I add my dissertation and publication of credits 46)

Yul: Kita sama, kan.

(We're the same, right)

Context:

Kho, An, and Yul are three doctoral students (S3). They are of the same class and courses per semester programmed by the three of them even though they are different. Following the new rules, the minimum credit for passing is 42 credits. 
(8) Fat: Sesi presentasi kita mulai, ya.

(Our presentation session is starting, yes)

Gus: Kelompok "Susu Sapi" siap?

(Ready for the "Cow's Milk" group?)

Ul: Kelompok "Amanda" dulu, Pak.

Context:

(The "Amanda" group first, Sir)

Fat is a resource companion in a PISA training with Junior High School teachers. Gus, the head of group I, discussed the causes of their students' mistakes in answering questions about the text "Amanda dan Sang Ratu (Amanda and the Queen)", while Ul was the leader of group IV on the text “Katakan 'Tidak' pada susu sapi (Say 'No' to cow's milk)". In addition, there are group II who handle the text "Hadiah (Prize)" and group III on the text "Forum Unggas (Poultry Forum)". Their task after the group discussion was a classical presentation.

The subjective functions are indicated by the use of pronouns and their substitutions. The use of a subject implies the use of politeness to which the kind of a subject is defined. The subject varies in terms of a noun, a single word, a phrase consisting of two or more words, and an adjective phrase.

\subsection{Adverbs}

Adverbial syntactical functions are indicated by the expression of a wish as an adverb of a sentence. In addition to predicates and subjects, as can be observed in Ma's utterance on data (9), Kin on data (10), and Don on data (11), pragmatic expressions that help identify the speaker's intent are also found in the description.

(9) Pri: Saat visitasi Jepang dan Sendratasik kemarin teman-teman banyak yang hadir? (During the Japanese visit and Sendratasik yesterday, many friends were present?)

Ma: Kemarin saya ada kelas, Bu. (Yesterday I had class, Ma'am)

Context:

Pri and Ma work together in the process of preparing for the visitation of the MA study program. Pri is positioned as a quality assurance center who accompanies Ma and the task force team in completing the preparation for the visitation. Before the visitation of the MA study program, there was a visitation of the Japanese Language Education Study Program and Sendratasik. The visitation of the two study programs may be attended by the task force team from the study program who wants to know the visitation process.

(10) Kin: Pak, Sabtu di rumah? Ingin minta tanda tangan BKD.

(Mr, Saturday at home? Want to ask for the BKD signature)

Har: Di rumah, Mas. Jadi lanjut studi tahun ini?

(At home, Sir. Do you continue study this year?)

Kin: Insya Allah tahun depan, Pak.

(Insya Allah next year, Mr.) 
Context:

Kin is a postgraduate (S2) alumni from the university where Har works. Several months earlier, Har suggested Kin continue his studies so that in addition to increasing research opportunities and academic competence, he also suited his position as dean of a private university. At that time, Kin was still thinking and could not make a decision.

(11) Don: Pak, kami dapat hibah kurikulum merdeka belajar. Untuk kepentingan narasumbernya maunya teman-teman adalah Bapak. Kira-kira bisanya kapan ya, Pak?

(Sir, we got a free learning curriculum grant. For the benefit of the resource person, friends want you to be you. How long can it be, sir?)

Har: Saya manut ("ikut"), Mas.

(I'm obedient ("follow"), Sir.)

Don: Kalau Rabu?

(What about Wednesday?)

Har: Rabu saya ada kegiatan dengan dinas, Mas. Hari Sabtu, teman-teman bisa?

(Wednesday I have an activity with the official, Sir. Saturday, are you able friends?)

Don: Kalau hari kerja bisanya hari apa ya, Pak?

(If weekdays, what day do you able, Sir?)

Har: Senin, ya.

(Monday, yes)

Context:

Don was chair of a certain course at a different university from where Har worked. Har is a senior lecturer who in the view of Don and his friends understands the curriculum for independent learning.

Evidence on adverbial syntactical functions indicates that intentions are stressed as in a sentence for two places: at the beginning of a sentence and the end of a sentence. The pragmatic expressions in this context are emphasized as the structure of a sentence to acknowledge the time, frequency, quality, or size of a subject. Of course, the expressions are also attached to the condition of the intention to which an adverb is emphasized using politeness principles.

\section{DISCUSSION}

This study looks at three main parts of a syntactic function of conversation spoken in the academic contexts. The syntactical functions are predicate, subject, and adverbs. The evidence shows that in predicative syntactical functions, the use of verbs is emphasized as the core message. As a predicate, it expresses a tone that has no expression, politeness, and violation of Grice maxim. The subject of conversation syntactically indicates how the intention of pragmatic expressions is emphasized in a subject of a sentence. The adverbial syntactical functions indicate the time, frequency, quality, or size of a subject. The emphasis is on what conditions a wish is delivered by a speaker to address a topic. Any kind of syntactical function 
is used when it expresses a pragmatic goal; politeness is present. Let's now see the discussion of each research question in this study.

\subsection{Predicative Syntactical Function}

The evidence of predicative syntactical functions appears in Jay's motivation in maintaining the predicate on the implicature he conveys. In maintaining the predicate, the mechanism used is the predicate in the utterance of the speaker (originally the hearer is presented as a speaker) is presented, and the speaker is substituted by another party, in this case, "tim sekarang (current team)". The pragmatic expression of the predicate filler that is maintained in the speaker implicature is not always intact. As presented in Saf's speech in data (2), Lid on data (3), Ris on data (4), and Luf in data (5), the pragmatic expression of the retained predicate filler can be partially, thereby having the status as predicate constituents.

The pragmatic expression of the filler in Saf's utterance is "sudah selesai (finished)", while the implication is that in chapter IV Saf is not finished. When the pragmatic expressions "sudah selesai (finished)" and "belum selesai (not finished)" are compared, it appears that the similarities are at the constituent predicate level. The expression "sudah (already)" shifted to "belum (not yet)" as a result of using part of the subject's motion. As explained in the context, the complete notion of the subject is the first, second, and third problem; while what Saf says is only the first and second issue. The mechanism for the mention of some of the notes causes the meaning of "sudah (already)" to change to "belum (not yet)".

A contrasting mechanism with Saf's utterance, in the sense of mentioning more nosi, is found in Lid's utterance in the data (3). If Saf in data (2) mentions "dua dari tiga (the two out of three)", Lid mentions "dua puluh dari lima (twenty out of five)". The mention of this difference in number has an impact on implicature orientation: the use of pragmatic expressions that negates less in Saf's utterance is action-oriented, while those that contribute more to Lid's utterance are affirmative oriented. Thus, the implicature of Lid's utterance is that there is still any space.

The predicate in Ris's utterance on data (4) is "sudah pernah mundur (has been resigned)", Luf in data (5) is "tinggal di kos (living in a boarding house)", and Tin in data (6) is "menunggu (waiting)" and "baru transfer (just transferring)". The implications of their utterances are "Bapak jangan mundur (Sir, don't resign)", "saya tidak tinggal bersama ayah (I don't live with father)", and "saya belum transfer (I haven't transferred yet)" The pragmatic expression "mundur (resign)" is found in both the predicate and the Ris implicature, "tinggal (stay)" is found in both the predicate and the Luf implicature, and "transfer" is found in both the predicate 
and the implicature of Tin. The existence of pragmatic expressions in the predicate thus helps speech partners in identifying implicatures because speech partners only need to add some of the pragmatic expressions related to the context.

This study confirms the finding of Suhartono (2020b) and Qasim (2019). In this study, conversational implications are bound by the context of the conversation, whereas conventional implications are bound by convention. The predicate of a sentence fully expresses a pragmatic expression that is easily identified by the counterpart (Abdul \& Qassim, 2015). The predicate is the most important syntactic function because it is mandatory for all types of sentences (Sugono, 2013). It implies that the goal of a conversation can be easily identified in a subject of a sentence from which an utterance is delivered (Alwi et al., 2019; Suhartono \& Sodiq, 2019).

\subsection{Subject Syntactical Functions}

Evidence of subject as the syntactical function can be viewed from the formulation point of view the intention is the first stage in speaking. In data of Mul, Ul, Fat, Rin, and Ji, they need not avoid the pragmatic expression of negation. The pragmatic expression indicates the use of subject fillers or subject constituents used by speech partners. Pragmatic expressions used by speech partners can be completely copied and pasted, such as those in Rat's utterance, or modified according to the needs of the utterance, such as those in An and Lid's utterance.

This finding reveals that a subject to show a pragmatic expression takes place as a noun, phrase, or an adjective phrase. In an academic context, a subjective syntactical function contributes to an indirectness that indicates an unexpressed meaning. (Cruse, 2000; Koktová, 1998; Mey \& Brown, 2009) emphasize that meaning in a conversation is not always stated (not encoded) in an explicit statement. A subject puts the context of a conversation (Nordquist, 2019). The context can provide insights where the speaker cannot be understood without full involvement of the context (Abdul \& Qassim, 2015; Ariel, 2008; Leech, 1983; Suhartono, 2020a, 2020c).

\subsection{Adverbial Syntactical Function}

Following its clause explaining features and can be mutated freely, the pragmatic expressions of the rest of conversations, such as "kemarin (yesterday)", "tahun depan (next year)", and "kalau hari kerja (if it's a weekday)". The implications of the speeches of Ma, Kin, and Don respectively are "Kemarin saya tidak hadir (Yesterday I was not present)", "Saya tidak jadi lanjut studi tahun ini (I will not continue my studies this year)", and "Hari Sabtu temanteman tidak bisa (Saturday, my friends couldn't)". It appears that the pragmatic expressions of 
"kemarin (yesterday)", "tahun (year)" and "hari (day)" in Ma, Kin, and Don's utterances helped the speech partners understand the implications they conveyed.

As well as speakers of the predicate and subject syntactic functions described above, some data also intended to convey disagreements. For the utterance to be polite, disagreement is conveyed indirectly by not using the negation markers "tidak (no)", "bukan (not)", and the like. For this purpose, Ma uses the strategy of using the reasoning "ada kelas (there is class)", Kin uses the pledge strategy, and Don uses the alternative giving strategy.

The adverbial syntax to indicate a pragmatic expression follow the use of adverbs in a sentence form varying in the beginning or at the end of a sentence. The expressions to show politeness may be defined in an indirect sentence or the use of explicit terms as in academic discourse.

This finding is in agreement with Suhartono (2020a, 2020c) to which an issue of the full syntactic function and politeness are emphasized in a conversation (Sugono, 2013). Syntactically, a subject is a companion of the predicate (Parera, 2009), located to the left or right of the predicate (Alwi et al., 2019; Sugono, 2013; Suhartono, 2020a). As the full syntactic function, adverbs may express maxim of quality, time, frequency, and manners (Cruse, 2000; Grice, 1975; Koktová, 1998; Leech, 1983; Mey \& Brown, 2009). In addition, politeness is easily represented both in negative or positive politeness (Abdul \& Qassim, 2015; Leech, 1983; Nordquist, 2019; Suhartono, 2020c).

Drawing the pragmatic expressions in the context of the academic environment, this study implies that the predicative expression, the subjective expression, and the adverbial expression as well are the main attributes in the academic conversation to which meaning and politeness are addressed. This study implies a novelty that utterances to show the academic contexts in this study are identified with the presence of the subject and adverb of a sentence where politeness is controlled.

\section{CONCLUSION}

Pragmatic expressions of the syntactic function of the predicate, subject, and description in speech implicated in conversation are the result of the speaker's selection of many other pragmatic expressions. When a pragmatic expression is chosen, the basis is that the pragmatic expression is representative to represent the meaning conveyed and under the knowledge relevant to the context of the speech. This suggests that the identification of pragmatic expressions of the filler of the syntactic function of the predicate, subject, and information is important for speakers because these expressions can be used to aid in interpreting the 
speaker's implicature. This pragmatic expression can be positioned as a full filler of certain syntactic functions, or as a constituent filler. The existence of pragmatic expressions on the syntactic functions of predicates, subjects, and statements as "device" for interpreting implicatures in this case is seen as a new perspective that differs from the old view that interpretations of speaker implicatures are based entirely on context.

Identification of pragmatic expressions is preceded by identification of the dichotomy of speaker intent. In this case, there are two dichotomous alternatives: the speaker's utterance is in line with or not in line with the speaker's intent (originally the speaker is in the position of the speaker). If the speaker's intent is identified, the hearer identifies the pragmatic expression selection strategy used by the speaker, for example, the strategy of substitution, addition, and conditional forms with an orientation prioritizing politeness through avoiding direct utterance delivery marked with the negation "tidak (no)", "belum (not yet)", "bukan (not)", and "jangan (do not)".

\section{REFERENCES}

Abdul, S., \& Qassim, M. (2015). The syntactic, semantic and pragmatic study of questions in selected conversations. Journal of the College of Languages, 32, 270-288. https://www.iasj.net/iasj?func=article \&aId=103064

Allan, K. (1998). Speech act hierarchy: Locutions, illocutions, and perlocutions (J. L. Mey). Elsevier.

Alwi, H., Dardjowidjojo, S., Lapoliwa, H., \& Moeliono, A. M. (2019). Tata bahasa baku bahasa Indonesia. Balai Pustaka.

Ariel, M. (2008). Pragmatics and grammar. In the series Cambridge textbooks in linguistics. Cambridge University Press.

Austin, J. L. (1975). How to do things with words. Oxford University Press.

Bach, K., \& Harnish, R. M. (1979). Linguistic communication and speech acts. Mas \&. Inc.

Berge, K. L. (1994). Communication. In Concise Encyclopedia of Philosophy of Language (J. L. Mey, pp. 92-102). Elsevier.

Brown, P., Levinson, S. C., \& Levinson, S. C. (1987). Politeness: Some universals in language usage. Cambridge University Press.

Cruse, D. A. (2000). Meaning in language: An introduction to semantics and pragmatics. Oxford University Press.

Dik, S. J., \& Kooij, J. G. (1994). Ilmu bahasa umum (Kamil T. W. (trans) (ed.)). RUL.

Fajaruddin, S. (2011). Analisis prinsip kerja sama Grice dalam naskah drama Dr. med.hiob. Prätorius karya Kurt Goetz. Fakultas Bahasa dan Seni Universitas Negeri Yogyakarta.

Grice, H. P. (1975). Logic and conversation. In P. Cole \& J. L. Morgan (Eds.), Speech Acts (pp. 41-58). BRILL. https://doi.org/10.1163/9789004368811_003

Koktová, E. (1998). Conversational implicature (J. L. Mey). Elsevier.

Leech, G. (1983). The priciple of pragmatics. Longman Group Limited.

Mey, J. L., \& Brown, K. (2009). Concise encyclopedia of pragmatics. Elsevier Science. 
Miles, M. B., \& Huberman, A. M. (1994). Qualitative data analysis: An expanded sourcebook. SAGE Publications Ltd.

Miles, M. B., Huberman, A. M., \& Saldaña, J. (2014). Qualitative data analysis: A methods sourcebook. Sage.

Nordquist, R. (2019). Pronoun reference in English grammar. ThoughtCo.

Parera, J. D. (2009). Dasar-dasar analisis sintaksis. Erlangga.

Searle, J. R. (1975). Indirect speech acts. In P. Cole \& J. L. Morgan (Eds.), Syntax and Semantics (pp. 59-82). Academic Press.

Searle, J. R., \& Searle, J. R. (1969). Speech acts an essay in the philosophy of language. Cambridge University Press.

Sugono, D. (2013). Mahir berbahasa Indonesia dengan benar. Gramedia Pustaka Utama.

Suhartono, S. (2020a). Implications of academic interactions in the graduated thesis exam contect in Indonesia University. The Asian ESP Journal, 16(1.2), 321-334.

Suhartono, S. (2020b). On spoken implicature of daily conversation" How social values form utterances. The Asian ESL Journal, 27(2.2), 124-136.

Suhartono, S. (2020c). Pragmatik konteks Indonesia. Graniti.

Suhartono, S., \& Sodiq, S. (2019). Psikolinguistik. Universitas Terbuka Press.

Suhartono, S., \& Yuniseffenri, Y. (2009). Pragmatik. Universitas Terbuka Press.

Yule, G. (1998). Pragmatics. Oxford University Press. 